\title{
Residual contact toxicity and repellence of Cupressus lusitanica Miller and Eucalyptus saligna Smith essential oils against major stored product insect pests
}

\author{
Philip K. Bett ${ }^{\mathrm{a}, *}$, Arop L. Deng ${ }^{\mathrm{b}}$, Joshua O. Ogendo ${ }^{\mathrm{c}}$, Samuel T. Kariuki ${ }^{\mathrm{a}}$, \\ Maud Kamatenesi-Mugisha $^{\mathrm{d}}$, Joel M. Mihale ${ }^{\mathrm{e}}$, Baldwyn Torto ${ }^{\mathrm{f}}$ \\ a Department of Biological Sciences, Egerton University, P.O. Box 536-20115, Egerton, Kenya \\ b College of Natural Resources and Environmental Studies, University of Juba, P.O. Box 82, Juba, South Sudan \\ ${ }^{\mathrm{c}}$ Department of Crops, Horticulture and Soils, Egerton University, P.O. Box 536-20115, Egerton, Kenya \\ d Bishop Stuart University, P.O. Box 09, Mbarara Municipality, Mbarara District, Uganda \\ e Department of Physical Sciences, Open University of Tanzania, P.O. Box 31608, Dares Salaam, Tanzania \\ ${ }^{\mathrm{f}}$ Behavioural and Chemical Ecology Department, icipe, P.O. Box 30772-00100, Nairobi, Kenya
}

\section{A R T I C L E I N F O}

\section{Keywords:}

Cupressus lusitanica

Essential oil

Eucalyptus saligna

Insect pest

Mortality

Repellence

\begin{abstract}
A B S T R A C T
In an effort to find eco-friendly alternatives to synthetic pesticides in grain storage, residual contact toxicity and repellence of Cupressus lusitanica and Eucalyptus saligna leaf essential oils were evaluated against adult Tribolium castaneum, Acanthoscelides obtectus and Sitophilus zeamais. In bioassays, oil was applied at 0.00, 0.05, 0.10, 0.15 and $0.20 \% \mathrm{v} / \mathrm{w}$ to wheat and bean grains and stored for 30-120 days after which test insects were introduced into sub-samples of treated grains. Both oils at $0.20 \% \mathrm{v} / \mathrm{w}$ and 120 days grain storage duration caused a mortality of 5.0-65.0\% in test insects whereas in the repellence bioassay, at same doses and grain storage duration produced percent repellence values of $34-52.4 \%$ of test insects. Considering other pesticidal properties of $C$. lusitanica and E. saligna oils, current results point oils as potential residual contact toxicants and repellents for possible integration into insect pest management practices.
\end{abstract}

\section{Introduction}

Insect pests cause $5-10$ and $20-30 \%$ damage to stored grains in the temperate and tropical countries, respectively (Philips and Throne, 2010). Post-harvest losses can include not only loss of the crop itself, but also lack of return on the resources needed to produce the crop, and a decrease in the livelihood of individuals involved in the production process (Bett, 2015). In addition, stored product pests also contaminate milled grains including presence of insect fragments in flour (Campolo et al., 2012). Several species of insects attributed to these losses and identified as the major insect pests of stored cereal and legume grains globally include, maize weevil, Sitophilus zeamais Motch. (Coleoptera: Curculionidae), Angoumois grain moth, Sitotroga cerealella Olivier (Lepidoptera: Gelechiidae), bostrichid beetles, Prostephanus truncatus Horn and Rhyzopertha dominica F. (Coleoptera: Bostrichidae), bean bruchid, Acanthoscelides obtectus Say (Coleoptera: Bruchidae), cowpea beetles, Callosobruchus chinensis F. (Coleoptera: Chrysomelidae), the rust-red flour beetle Tribolium castaneum Herbst (Coleoptera: Tenebrionidae) (Rajendran and Sriranjini, 2008; Deng et al., 2009; Nukenine, 2010;
Ogendo et al., 2012; Bett, 2015).

The bean bruchid, A. obtectus, together with cowpea beetles ( $C$. chinensis and $C$. maculatus) are destructors of stored legume grains. The bean bruchid is a major pest of beans in temperate to subtropical regions worldwide. The potential damage to stored grains by this pest is great owing to its ability to infest grains both pre- and post-harvest, and several larvae can develop in one seed (Ogendo et al., 2012; Bett et al., 2016). Sitophilus zeamais larvae damage maize crops by developing within an individual grain, eating it away from the inside out until it matures, and then reproducing, releasing more crop-damaging larvae. The maize weevil is a danger to both growing standing crops and stored maize (Ogendo et al., 2012). On the other hand, T. castaneum is a cosmopolitan stored product insect pest that can be found in warehouses, pet food stores, and grain processing facilities such as rice and flour mills. It is considered a secondary insect pest species and is frequently one of the least susceptible stored product beetle pest species to insecticides (Bett et al., 2016).

Stored product insect pest control is based mainly on the use of highly effective synthetic fumigants and contact toxicants. However,

\footnotetext{
* Corresponding author.

E-mail address: pkkbett@yahoo.co.uk (P.K. Bett).
} 
increased health, environmental and socio-economic concerns and the consequent demand for pesticide-free food, have necessitated the development of non-chemical strategies for stored pest management (Ayvaz et al., 2010). Among the natural products, plant essential oils and their constituents have the potential to control storage insect pests and preserve food commodities.

Many studies have demonstrated that essential oils extracted from different plants showed a broad spectrum of activity against insect pests of stored grains, including ovicidal, larvicidal, adulticidal, antifeedant, repellent, and growth regulatory activities (Abay et al., 2012; Bett et al., 2013, 2016). A number of essential oils and constituents have been classified as contact toxicants (Rosman et al., 2007; Ogendo et al., 2011; Abay et al., 2012; Bett et al., 2013) and repellents (Nerio et al., 2010; Ogendo et al., 2012; Bett et al., 2016). Studies on the biological activity of Eucalyptus species extracts and constituents have good promise as fumigants and contact toxicants, repellents (Nivea et al., 2013) against major pests of stored products. Additionally, Tapondjou et al. (2005) found essential oils extracted from $E$. saligna leaves to have toxic effects on $S$. zeamais $\left(\mathrm{LD}_{50}=0.36 \mathrm{ml} \mathrm{cm}^{-2}\right)$ and Tribolium confusum Jacquelin du Val (Coleoptera: Tenebrionidae) $\left(0.48 \mathrm{ml} \mathrm{cm}^{-2}\right)$. Probit analysis showed that $T$. confusum was comparatively more susceptible $\left(\mathrm{LD}_{50}=0.96 \mathrm{ml} \mathrm{cm}{ }^{-2}\right)$ to the toxic effect of cymol ( $p$-cymene), a major constituent of $E$. saligna oil than $S$. zeamais $\left(\mathrm{LD}_{50}=1.35 \mathrm{ml} \mathrm{cm}^{-2}\right)$.

The repellent ability of essential oils and constituents from these plant species has already been reported (Nerio et al., 2010; Mossi et al., 2011; Liu et al., 2011; Regnault-Roger et al., 2012). Demonstrated that essential oils and constituents obtained from Lantana camara L. (Verbenaceae), Ocimum americanum L. (Lamiaceae), and Tephrosia vogelii Hook (Fabaceae) were effective repellents against Sitophilus oryzae L. (Coleoptera: Curculionidae) T. castaneum, C. chinensis and R. dominica. In other related studies, Liang et al. (2013) showed that the essential oils of Curcuma longa L. (Zingiberaceae), Epimedium pubescens L. (Berberidaceae), Lindera aggregate Sims (Lauraceae), Nardostachys chinensis Don (Caprifoliaceae), Schizonepeta tenuifolia Siebold \& Zucc, Zanthoxylum schinifolium, and $Z$. officinale Roscoe (Zingiberaceae) exhibited strong repellent action against $T$. castaneum. The repellent action of the different essential oils against $T$. castaneum were reported to decrease in the order of Cymbopogon martini, C. flexuosus Roxb (poaceae) and Lippia origanoides L. (Verbenaceae) (Caballero-Gallardo et al., 2012).

The highly repellent effects of the main constituents of plant essential oils such as 1, 8-cineole, terpineol and $\alpha$-pinene have also been demonstrated by other researchers (Tapondjou et al., 2005; Toloza et al., 2006; Nivea et al., 2013). Toloza et al. (2006) demonstrated strong repellent activity of essential oil from Eucalyptus cinerea, E. viminalis Eucalyptus cinerea Muel (Myrtaceae) and E. saligna, against permethrin-resistant human head lice. The repellent effect was associated with $\alpha$-pinene 1, 8-cineole, citronellol, eugenol and camphor. Similarly, Eucalyptus citriodora Hook (Myrtaceae) and Cymbopogon winterianus L. (poaceae) oils are repellent to adult C. maculatus and repellence was associated with compounds like citronellal, 1, 8-cineole, limonene, geranial, neral, $(E)$-anethole, and $\alpha$-pinene (Nivea et al., 2013). Synthetic chemicals are still more frequently used as repellents than essential oils. However, these natural products have the potential to provide efficient and safer repellents to humans and the environment. Furthermore, natural repellents may be included in stored product pest management where chemical residues and insects in produce may not be tolerated by consumers.

Essential oil-based insecticides are, therefore, very important of the control stored product insects pests owing to their activity against a variety of insects, fast penetration and reduced toxic residues in the treated products (Mbata and Payton, 2013). However, setbacks of using essential oil include volatility, solubility and oxidation, which play an important role in the essential oil activity, application and persistence. The aim, therefore, of the current study was to evaluate residual contact toxicity and repellence of essential oils obtained from leaves of $C$. lusitanica and E. saligna against $T$. castaneum, A. obtectus and $S$. zeamais.

\section{Materials and methods}

\subsection{Experimental conditions and test insects}

The rearing of test insects and bioassays were carried out at the Integrated Biotechnology Laboratory, Egerton University, Kenya at controlled conditions of temperature $\left(28 \pm 2{ }^{\circ} \mathrm{C}\right)$ and relative humidity $(65 \pm 5 \%)$ in continuous darkness. Tribolium castaneum was reared in wheat flour and $5 \%$ brewers' yeast (wt:wt). Sitophilus zeamais and $A$. obtectus were reared on whole wheat and bean grains, respectively. One- five day old (T. castaneum and $S$. zeamais) and 1-2 day old (A. obtectus) emerging adult insects were used for bioassays. The grains used for the bioassays, were untreated, clean and infestation-free obtained from Kenya Agricultural and Livestock Research Organization, Njoro, Kenya.

\subsection{Essential oils}

The C. lusitanica and E. saligna leaf essential oils were provided by the Integrated Biotechnology Laboratory Egerton, Kenya. The hydrodistilled essential oils were previously subjected to Gas chromatography-Mass spectrometry analysis and results are already reported (Bett et al., 2016) (Table 1, Figs. 1 \& 2). C lusitanica oil was dominated by oxygenated monoterpenes whereas $E$. saligna oil was mainly monoterpene hydrocarbons. The major components found in C. luistanica oil were umbellulone $(18.38 \%), \alpha$-pinene $(9.97 \%)$, sabinene $(8.16 \%)$ and limonene $(7.91 \%)$ whereas E. saligna oil was dominated by 1 , 8-cineole (24.26\%), o-cymene (9.92\%) and $\alpha$-terpineol (8.81\%) (Bett et al., 2016) (Table 1).

\subsection{Residual toxicity bioassay}

Residual effects of essential oils of $C$. lusitanica and $E$. saligna on adult $A$. obtectus, $S$. zeamais and $T$. castaneum were evaluated according to the method of Asawalam et al. (2006) with modifications. The oils dissolved in acetone AR (99.8\% GC) were applied to $50 \mathrm{~g}$ wheat (or $100 \mathrm{~g}$ beans) grain samples in self-sealing polythene bags $(20 \mathrm{~cm} \times 25 \mathrm{~cm} ; 21$ capacity) at rates of $0.0,0.05,0.10,0.15$ and $0.20 \% \mathrm{v} / \mathrm{w}$. The grains were shaken thoroughly to ensure uniform distribution oil in grains. The solvent was allowed to evaporate for $1 \mathrm{~h}$ before polythene bags were sealed. The negative control consisted of untreated grains whereas Actelic Super ${ }^{\mathrm{TM}}(0.056 \% \mathrm{v} / \mathrm{w})$ and crude soya oil $(1.0 \% \mathrm{v} / \mathrm{w})$ served as positive controls. The bags were then sealed and transferred to an experimental room for long-term storage (120 days). A random sub-sample ( $10 \mathrm{~g}$ wheat and $20 \mathrm{~g}$ bean grains) was then drawn from each experimental unit at 30, 60, 90 and 120 days post- treatment. Into each sub-sample in $100 \mathrm{ml}$ jars, 20 unsexed test insects $\left(\mathrm{N}_{\mathrm{T}}\right)$ were introduced and the number of dead insects $\left(\mathrm{N}_{\mathrm{D}}\right)$ recorded $24,72,120$ and $168 \mathrm{~h}$ post- introduction of insects to estimate adult insect mortality. The percentage adult mortality was computed according to Asawalam et al. (2006) and corrected for natural mortality using Abbott's formula (Abbott, 1925), respectively in Eqs. (1) and (2)

Actual Mortality $(\%)=\frac{N_{D}}{N_{T}} \times 100$

Corrected Mortality $(\%)=\frac{\left(P_{O}-P_{C}\right)}{\left(100-P_{C}\right)} \times 100$

where $\mathrm{P}_{\mathrm{O}}$ represent observed and $\mathrm{P}_{\mathrm{C}}$ control percent mortalities; $\mathrm{N}_{\mathrm{D}}$ and $\mathrm{N}_{\mathrm{T}}$ represent number of dead and total number of test insects per jar.

\subsection{Residual repellency}

Each test essential oil was applied to $20 \mathrm{~g}$ wheat or $40 \mathrm{~g}$ bean grain samples in special self-sealing polythene bags $(20 \mathrm{~cm} \times 25 \mathrm{~cm} ; 21$ capacity) at five concentrations $(0,0.05,0.10,0.15$ and $0.20 \% \mathrm{v} / \mathrm{w})$. 
Table 1

Retention index \& time (min) and percent concentration of chemical constituents of leaf essential oils obtained from Eucalyptus saligna and C. lusitanica.

(Source: Bett et al., 2016).

\begin{tabular}{|c|c|c|c|c|c|}
\hline $\mathrm{No}^{\mathrm{a}}$ & Rt (min) & Compound Name & $\mathrm{RI}^{\mathrm{b}}$ & $\begin{array}{l}\% \text { E. } \\
\text { saligna }\end{array}$ & $\begin{array}{l}\% C . \\
\text { lusitanica }\end{array}$ \\
\hline 1 & 6.87 & 2,4-Dimethyl-3-pentanone & 804 & 0.09 & - \\
\hline 2 & 8.35 & Isovaleric acid & 861 & 0.24 & - \\
\hline 3 & 8.53 & 2-Methylbutanoic acid & 868 & 0.05 & - \\
\hline 4 & 8.63 & (Z)-3-Hexenol & 873 & 0.02 & - \\
\hline 5 & 8.82 & (E)-2-Hexen-1-ol & 880 & 0.02 & - \\
\hline 6 & 9.24 & $\begin{array}{l}\text { 1,2-Dimethyl-1,4- } \\
\text { cyclohexadiene }\end{array}$ & 896 & 0.02 & - \\
\hline 7 & 9.76 & $\begin{array}{l}\text { 2-Methylpropyl-2- } \\
\text { methylpropanoate }\end{array}$ & 918 & - & 0.12 \\
\hline 8 & 9.85 & Tricyclene & 922 & - & 0.06 \\
\hline 9 & 9.99 & $\alpha$-Phellandrene & 928 & 0.03 & 0.99 \\
\hline 10 & 10.12 & $\alpha$-Pinene & 935 & 24.40 & 9.97 \\
\hline 11 & 10.43 & $\alpha$-Fenchene & 948 & 1.58 & 0.51 \\
\hline 12 & 10.55 & Thuja-2,4(10)-diene & 954 & 0.11 & 0.06 \\
\hline 13 & 10.72 & Benzaldehyde & 962 & 0.05 & 0.01 \\
\hline 14 & 10.90 & 3-Methylbutyl propanoate & 969 & 0.12 & - \\
\hline 15 & 10.95 & Sabinene & 972 & 0.31 & 8.16 \\
\hline 16 & 11.29 & Myrcene & 987 & - & 2.29 \\
\hline 17 & 11.34 & (E)-Dehydroxylinalool oxide & 989 & 0.14 & - \\
\hline 18 & 11.58 & $\beta$-Phellandrene & 1000 & 0.16 & 0.48 \\
\hline 19 & 11.66 & $\delta$-3-Carene & 1005 & - & 6.93 \\
\hline 20 & 11.72 & Isoamyl isobutyrate & 1009 & 0.14 & - \\
\hline 21 & 11.80 & $\delta$-2-Carene & 1013 & - & 0.53 \\
\hline 22 & 11.95 & o-Cymene & 1023 & 9.92 & 5.81 \\
\hline 23 & 12.02 & Limonene & 1027 & - & 7.91 \\
\hline 24 & 12.10 & 1,8-Cineole & 1031 & 24.26 & - \\
\hline 25 & 12.17 & $(Z)$ - $\beta$-Ocimene & 1036 & 0.16 & 0.23 \\
\hline 26 & 12.31 & Phenylactealdehyde & 1045 & 0.12 & - \\
\hline 27 & 12.55 & $\gamma$-Terpinene & 1059 & 0.31 & 0.24 \\
\hline 28 & 12.71 & (E)-Sabinene hydrate(IPP vs OH) & 1069 & - & 0.47 \\
\hline 29 & 13.01 & p-Cymenene & 1092 & - & 1.33 \\
\hline 30 & 13.25 & Linalool & 1101 & - & 3.91 \\
\hline 31 & 13.32 & Isopentyl isovalerate & 1106 & 0.33 & - \\
\hline 32 & 13.48 & p-1,3,8-Menthatriene & 1115 & - & 0.16 \\
\hline 33 & 13.52 & endo-Fenchol & 1117 & 2.35 & - \\
\hline 34 & 13.56 & $\alpha$-Thujone & 1120 & - & 0.23 \\
\hline 35 & 13.64 & $p$-(Z)-Menth-2-en-1-ol & 1124 & - & 0.61 \\
\hline 36 & 13.72 & $\alpha$-Campholenal & 1129 & 1.81 & - \\
\hline 37 & 13.96 & $\begin{array}{l}\text { [1S-(1 } \alpha, 3 \alpha, 5 \alpha)]-6,6 \text {-dimethyl-2- } \\
\text { methylenebicyclo[3.1.1] heptan- } \\
\text { 3-ol }\end{array}$ & 1143 & 7.13 & - \\
\hline 38 & 14.03 & Camphor & 1147 & - & 0.62 \\
\hline 39 & 14.11 & Camphene hydrate & 1152 & 0.53 & - \\
\hline 40 & 14.24 & Sabina ketone & 1159 & - & 0.22 \\
\hline 41 & 14.33 & Pinocarvone & 1165 & 3.02 & - \\
\hline 42 & 14.39 & Borneol & 1168 & 4.57 & - \\
\hline 43 & 14.51 & Umbellulone & 1175 & - & 18.38 \\
\hline 44 & 14.54 & Terpinen-4-ol & 1177 & 1.52 & 6.12 \\
\hline 45 & 14.66 & $\begin{array}{l}{[\alpha, \alpha], 4 \text {-Trimethyl- }} \\
\text { benzenemethanol }\end{array}$ & 1184 & - & 1.25 \\
\hline 46 & 14.75 & $\alpha$-Terpineol & 1189 & 8.81 & 1.98 \\
\hline 47 & 14.86 & $\gamma$-Terpinen-7-al & 1207 & - & 0.19 \\
\hline 48 & 15.06 & Verbenone & 1208 & 0.53 & - \\
\hline 49 & 15.24 & Eucarvone & 1220 & - & 0.37 \\
\hline 50 & 15.33 & Terpinolene & 1227 & 1.43 & - \\
\hline 51 & 15.51 & Cumin aldehyde & 1238 & & 0.31 \\
\hline 52 & 15.71 & Piperitone & 1252 & 0.28 & 1.19 \\
\hline 53 & 16.19 & Thymol & 1284 & 0.27 & 0.76 \\
\hline 54 & 16.30 & Benzyl isobutanoate & 1291 & 0.08 & - \\
\hline 55 & 16.33 & Terpinolene & 1293 & - & 0.66 \\
\hline 56 & 17.02 & $\alpha$-Terpinene & 1342 & - & 2.60 \\
\hline 57 & 17.10 & $\begin{array}{l}\text { 2,2,5,5-Tetramethyl-3- } \\
\text { cyclopenten-1-one }\end{array}$ & 1348 & 0.15 & - \\
\hline 58 & 17.44 & $\alpha$-Copaene & 1373 & 0.11 & - \\
\hline 59 & 17.62 & Phenylethyl butyrate & 1386 & 0.19 & - \\
\hline 60 & 17.71 & (E)-Jasmone & 1392 & 0.13 & - \\
\hline 61 & 17.78 & 3-Isopropylbenzaldehyde & 1397 & - & 0.16 \\
\hline 62 & 17.90 & Premnaspirodiene & 1407 & - & 0.09 \\
\hline 63 & 17.98 & $\alpha$-Cedrene & 1412 & - & 0.09 \\
\hline 64 & 18.06 & (E)-Caryophyllene & 1418 & - & 0.18 \\
\hline 65 & 18.31 & Germacrene B & 1438 & 0.08 & - \\
\hline
\end{tabular}

Table 1 (continued)

\begin{tabular}{|c|c|c|c|c|c|}
\hline $\mathrm{No}^{\mathrm{a}}$ & $\mathrm{Rt}(\min )$ & Compound Name & $\mathrm{RI}^{\mathrm{b}}$ & $\begin{array}{l}\% \text { E. } \\
\text { saligna }\end{array}$ & $\begin{array}{l}\text { \% C. } \\
\text { lusitanica }\end{array}$ \\
\hline 66 & 18.37 & (E)-Muurola-3,5-diene & 1443 & - & 0.54 \\
\hline 67 & 18.59 & $\alpha$-Guaiene & 1459 & 0.15 & - \\
\hline 68 & 18.61 & (E)-Muurola-4(14),5-diene & 1461 & - & 3.40 \\
\hline 69 & 18.69 & $\alpha$-Macrocarpene & 1467 & - & 0.19 \\
\hline 70 & 18.76 & $\alpha$-Curcumene & 1473 & - & 0.21 \\
\hline 71 & 19.02 & Viridiflorene & 1492 & 0.09 & 0.00 \\
\hline 72 & 19.01 & Epizonarene & 1492 & - & 0.73 \\
\hline 73 & 19.07 & $\beta$-Macrocarpene & 1497 & - & 0.18 \\
\hline 74 & 19.14 & $\beta$-Vetivenene & 1502 & - & 0.11 \\
\hline 75 & 19.24 & Durohydroquinone & 1510 & 0.09 & - \\
\hline 76 & 19.33 & (Z)-Calamenene & 1518 & - & 1.98 \\
\hline 77 & 19.51 & $\alpha$-Dehydro-ar-himachalene & 1533 & - & 0.35 \\
\hline 78 & 19.59 & $\beta$-Calacorene & 1539 & - & 0.43 \\
\hline 79 & 19.82 & $\gamma$-Gurjunene & 1558 & 0.05 & - \\
\hline 80 & 19.83 & $\alpha$-Calacorene & 1559 & - & 0.12 \\
\hline 81 & 19.93 & Pogostol & 1567 & 0.08 & - \\
\hline 82 & 20.03 & Spathulenol & 1576 & 0.43 & 0.05 \\
\hline 83 & 20.11 & Caryophyllene oxide & 1582 & - & 0.23 \\
\hline 84 & 20.11 & Globulol & 1582 & 0.17 & - \\
\hline 85 & 20.43 & iso-Leptospermone & 1608 & 3.23 & - \\
\hline 86 & 20.45 & 1,10-di-epi-Cubenol & 1611 & - & 0.35 \\
\hline 87 & 20.51 & $\alpha$-Colocalene & 1616 & - & 0.08 \\
\hline 88 & 20.65 & $\beta$-Gurjunene & 1628 & 0.08 & - \\
\hline 89 & 20.65 & $\beta$-Acoradiene & 1628 & - & 0.36 \\
\hline 90 & 20.75 & (Z)-Cadina-1(6),4-diene & 1637 & - & 0.26 \\
\hline 91 & 20.91 & $\beta$-Eudesmol & 1650 & - & 0.43 \\
\hline 92 & 21.13 & Cadalene & 1670 & - & 0.14 \\
\hline 93 & 21.33 & (Z)-14-nor-Muurol-5-en-4-one & 1688 & - & 1.89 \\
\hline 94 & 21.46 & 10-nor-Calamenen-10-one & 1699 & - & 0.17 \\
\hline 95 & 22.55 & (Z)-5-Hydroxy-calamenene & 1823 & - & 0.08 \\
\hline 96 & 23.61 & Isopimara-9(11),15-diene & 1926 & - & 0.14 \\
\hline 97 & 23.94 & Kaur-15-ene & 1961 & - & 0.03 \\
\hline 98 & 24.26 & Sandaracopimara-8(14),15-diene & 1996 & - & 0.22 \\
\hline 99 & 24.52 & 13-epi-Manool oxide & 2024 & - & 0.27 \\
\hline 100 & 25.37 & Abietadiene & 2115 & - & 0.12 \\
\hline 101 & 25.81 & Nezukol & 2163 & - & 0.68 \\
\hline 102 & 27.35 & (E)-Totarol & 2342 & - & 0.08 \\
\hline
\end{tabular}

$-=$ Absent.

${ }^{\mathrm{a}}$ No $=$ Peak numbers as indicated in Figs. $1 \& 2$.

${ }^{\mathrm{b}} \mathrm{RI}=$ Retention Index.

DEET treated and untreated grains were used as positive and negative controls, respectively. The treated grains were transferred to the experimental room for long-term storage (120 days). A random subsample of $2 \mathrm{~g}$ wheat and $4 \mathrm{~g}$ beans were then drawn from each experimental unit at 30,60, 90 and 120 days post-treatment. The base of a 14-cm diameter glass Petri-dish was lined with aluminum foil, divided into four equal parts and treated grain samples placed in each quarter equidistant to the center in an alternate untreated (control)-treated arrangement with four replicates per concentration. Twenty (20) unsexed adult stages of $A$. obtectus, $S$. zeamais, and T. castaneum were then released at the center of petri-dish and the top secured by its cover. The number of insects present in the control $\left(\mathrm{N}_{\mathrm{C}}\right)$ and treated $\left(\mathrm{N}_{\mathrm{T}}\right)$ grains were recorded 1, 3, 5 and 24 h post- exposure. Percent repellence (PR) values were computed according to Asawalam et al. (2006)

Percent repellence $(P R)=\frac{\left(N_{C}-N_{T}\right)}{\left(N_{C}+N_{T}\right)} \times 100$

\subsection{Statistical data analysis}

The experimental design used was a completely randomized design (CRD) with four replicates per concentration in all bioassays. The concentrations of essential oils used were 0.0, 0.05, 0.10, 0.15 and $0.20 \% \mathrm{v} / \mathrm{w}$ and these were replicated four times. Adult insects were picked at random and placed in glass jars and petri-dishes accordingly.

The data on insect mortality were corrected for natural mortality using Abbott's formula (Abbott, 1925). In addition, the data on 


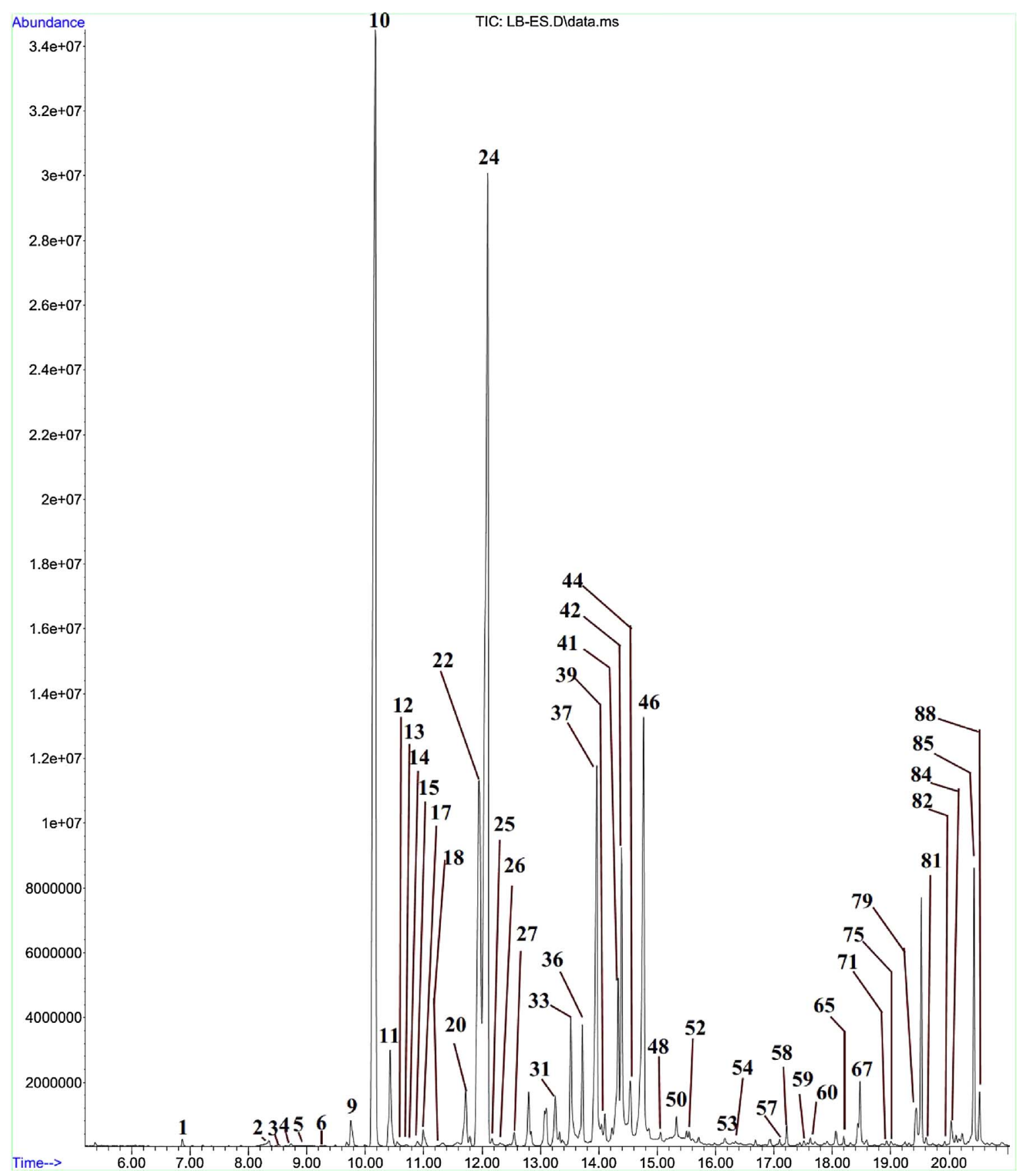

Fig. 1. Chromatogram of the leaf essential oil of Eucalyptus saligna. Peaks 1-88 show the essential oil components identified.

(Source: Bett et al., 2016).

corrected percentage insect mortality and percentage repellence were homogenized using angular transformation (Sokal and Rohlf, 1995), before being subjected to two-way Analysis of Variance (multiple comparisons) (SPSS, 2010). The means were separated using Tukey Honestly Significant Difference (HSD) test at the 5\% significance level (Sokal and Rohlf, 1995). For the relationship between doses of essential oils used and insect mortality, the lethal concentration that killed $50 \%$ $\left(\mathrm{LC}_{50}\right)$ of test insects was determined using Probit Regression Analysis (SPSS, 2010). In a column, any two calculated $\mathrm{LC}_{50}$ values whose $95 \%$ feducial limits did not overlap were considered as significantly different (Finney, 1971).

\section{Results}

\subsection{Residual contact toxicity}

The $C$. lusitanica leaf essential oils produced dose-, insect speciesand storage duration-dependent residual contact toxicity against adult T. castaneum, A. obtectus and S. zeamais. At $0.20 \% \mathrm{v} / \mathrm{w}$ and treated grain storage period of 30 days, $C$ lusitanica leaf essential oils caused 6.3, 25.0 and $85.0 \%$ kill of adult $T$. castaneum, $S$. zeamais and A. obtectus, respectively, $168 \mathrm{~h}$ post-introduction of test insects (Fig. 3a). The C. lusitanica oil treated grains stored for 30 days was toxic to adult $S$. zeamais and $A$. obtectus with $\mathrm{LC}_{50}$ values of 0.07 and $0.12 \% \mathrm{v} / \mathrm{w}$, respectively $168 \mathrm{~h}$ post-introduction of test insects. On the other hand, the oil at the same concentration was less toxic to T. castaneum with $\mathrm{LC}_{50}$ of $0.79 \% \mathrm{v} /$ 


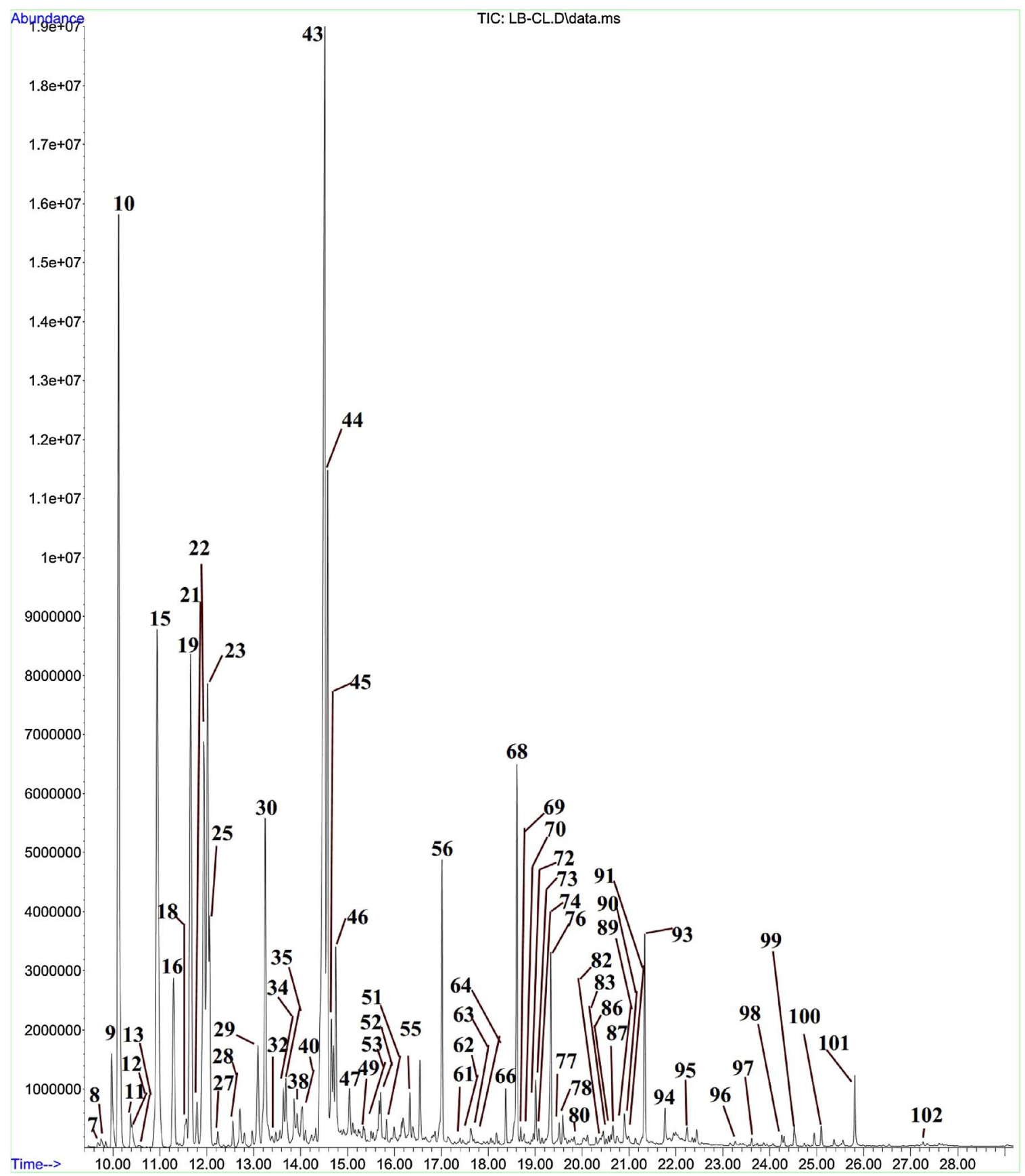

Fig. 2. Chromatogram of the leaf essential oil of Cupressus lusitanica. Peaks 7-102 show the essential oil components identified. (Source: Bett et al., 2016).

$\mathrm{w}, 168 \mathrm{~h}$ post-introduction of test insects (Table 2). However, at the same concentration and 120 days grain storage duration, $C$ lusitanica oils caused a mortality of 5.0, 17.5 and $65.0 \%$ in adult $S$. zeamais, $T$. castaneum and $A$. obtectus, respectively $90 \mathrm{~h}$ post-introduction of test insects (Fig. 4a). At the longest storage duration of 120 days, C. lusitanica oil was also toxic to T. castaneum and A. obtectus and S. zeamais, with $\mathrm{LC}_{50}$ values of $0.12,0.13$ and $0.38 \% \mathrm{v} / \mathrm{w}$, respectively $168 \mathrm{~h}$ post introduction of test insects (Table 2).

The E. saligna oils also produced dose-, insect species- and storage duration-dependent residual contact toxicity against T. castaneum, A. obtectus and $S$. zeamais. Results also indicated that at a dose of $0.20 \% \mathrm{v} /$ $\mathrm{w}, E$. saligna oil was highly efficacious over treated grain storage period of 30 days causing $32.5,90.0$ and $93.0 \%$ mortality against adult $T$. castaneum, S. zeamais and A. obtectus, respectively $168 \mathrm{~h}$ post-introduction of test insects (Fig. 3b). E. saligna oil treated grain storage period of 30 days had similarly high toxicity levels with $\mathrm{LC}_{50}$ values of 0.003 and $0.005 \% \mathrm{v} / \mathrm{w}$ for $A$. obtectus and $S$. zeamais respectively $168 \mathrm{~h}$ post-introduction of test insects. T. castaneum was more tolerant, with $\mathrm{LC}_{50}$ values of $0.51 \% \mathrm{v} / \mathrm{w} 168 \mathrm{~h}$ post-introduction of test insects (Table 3).

The same results trend was observed at same concentration and 120 days grain storage duration where $S$. zeamais and $A$. obtectus were most susceptible to E. saligna oil causing mortalities of 90 and $93 \%$, respectively $168 \mathrm{~h}$ post-introduction of test insects (Fig. 4b). However, at the same concentration and 120 days grain storage duration, E. saligna oils caused a mortality of 5.0, 60.0 and $64.2 .0 \%$ in $T$. castaneum, $S$. zeamais and $A$. obtectus, respectively $168 \mathrm{~h}$ post-introduction of test insects. Similar $\mathrm{LC}_{50}$ values were observed for $E$. saligna oil after 120 days grain storage duration with T. castaneum, S. zeamais and A. obtectus recording $\mathrm{LC}_{50}$ values of $0.04,0.10$ and $0.70 \% \mathrm{v} / \mathrm{w}$ respectively 

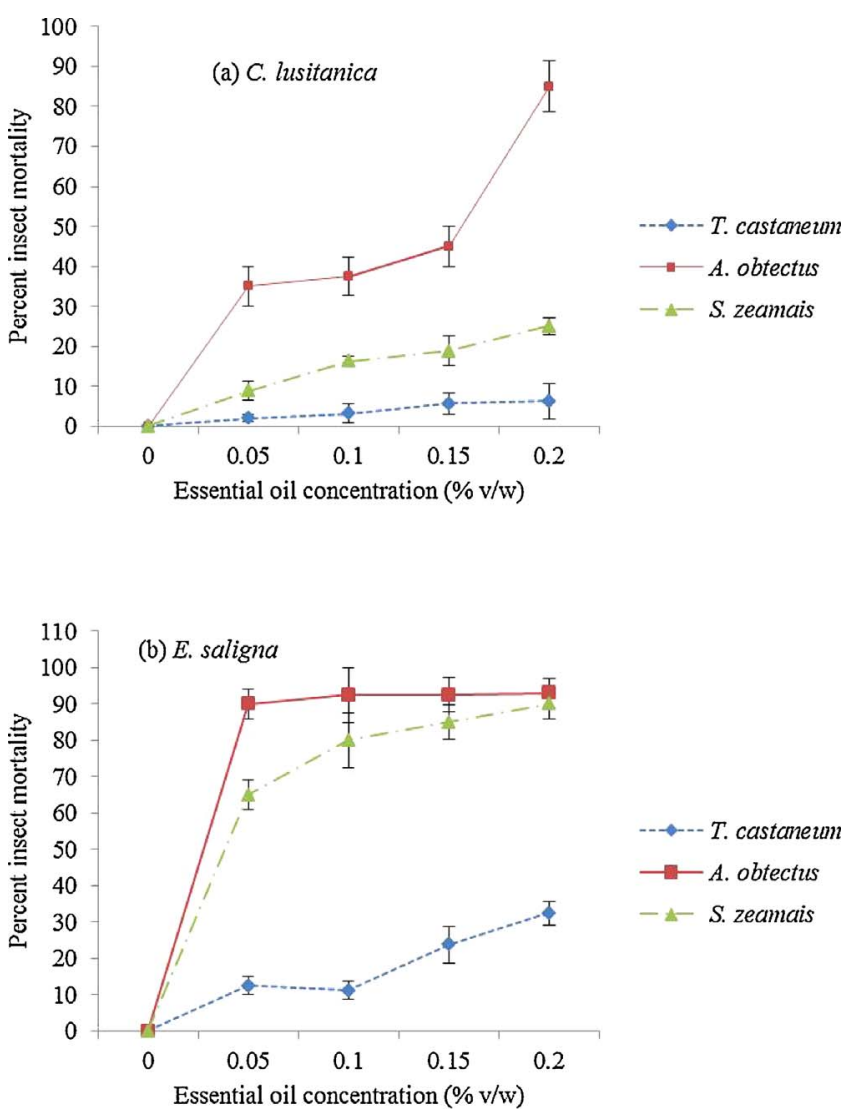

Fig. 3. Percent mortality (Mean $\pm \mathrm{SE}, \mathrm{n}=4$ ) of $T$. castaneum, A. obtectus and $S$. zeamais after 30 days contact with five concentrations (v/w) of (a) C. lusitanica and (b) E. saligna leaf essential oils.

$168 \mathrm{~h}$ post-introduction of test insects (Table 3). By comparison, $A$. obtectus was the most susceptible whereas $T$. castaneum was the most tolerant of the three insect species to $C$ lusitanica oils.

\subsection{Residual repellence of essential oils}

\subsubsection{C. lusitanica essential oil}

Results of residual repellence of $C$. lusitanica leaf essential oils against S. zeamais, T. castaneum and A. obtectus after 30-120 days of grain storage are presented in Fig. 5. The C. lusitanica leaf essential oils produced a dose-, grain storage duration- and exposure time-dependent percent residual repellence against adult $T$. castaneum, $A$. obtectus and $S$. zeamais. Data also showed that, at the highest concentration of $0.20 \%$ $\mathrm{v} / \mathrm{w}$ and 30 days grain storage duration, $C$. lusitanica leaf essential oil was moderately repellent to $S$. zeamais $(49.3 \%)$ but produced low PR values against $T$. castaneum (13.2\%) and A. obtectus (32.2\%) $12 \mathrm{~h}$ postintroduction of test insects (Fig. 3). At the same concentration and 120 days grain storage duration, the oil was moderately repellent with PR values of $37.9,47.6$ and $51.1 \%$ against adult $A$. obtectus. S. zeamais and $T$. castaneum, respectively $12 \mathrm{~h}$ post-introduction of test insects (Fig. 5).

\subsubsection{E. saligna essential oil}

Data on residual repellence of $E$. saligna leaf essential oils against $S$. zeamais, T. castaneum and A. obtectus after 30-120 days grain storage duration are presented in Fig. 6 . The E. saligna leaf essential oils produced dose-, grain storage duration- and exposure time-dependent residual PR against adult $T$. castaneum and $S$. zeamais except $A$. obtectus in which all factors were insignificant. The PR values for $E$. saligna essential oils, at $0.20 \% \mathrm{v} / \mathrm{w}$ and 30 days grain storage duration, against adult $A$. obtectus, $S$. zeamais and T. castaneum were $17.8 \%, 22.9 \%$ and $33.6 \%$, respectively, $12 \mathrm{~h}$ post-introduction of test insects (Fig. 4). Similarly, at the same concentration and 120 days grain storage duration; oil was moderately repellent with a PR value of $52.4 \%$ in $T$. castaneum but weakly repellent to A. obtectus (34.0\%) and S. zeamais (36.6\%), $12 \mathrm{~h}$ post-introduction of test insects (Fig. 6).

\section{Discussion}

From the results of residual contact toxicity, C. lusitanica and E. saligna essential oils exhibited concentration- and storage and contact duration-dependent toxicity against $S$. zeamais, T. castaneum and A. obtectus. The fact that oils at a concentration of $0.20 \% \mathrm{v} / \mathrm{w}$ and storage duration of 30-120 days caused moderate to high mortalities of $S$.

Table 2

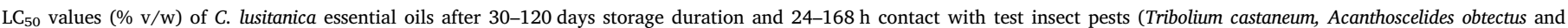
Sitophilus zeamais).

\begin{tabular}{|c|c|c|c|c|}
\hline \multirow[b]{2}{*}{${ }^{\mathrm{a}}$ Insect/Time (h) } & \multicolumn{4}{|c|}{ Grain Storage Duration (Days) } \\
\hline & 30 & 60 & 90 & 120 \\
\hline \multicolumn{5}{|l|}{ T. castaneum } \\
\hline 24 & $0.29\left(0.20,2.59^{\mathrm{a}}\right)$ & $22.5(-)^{b}$ & $3.05(-)^{\mathrm{b}}$ & $0.78(-)^{\mathrm{b}}$ \\
\hline 72 & $0.29(0.18,6.51)^{\mathrm{c}}$ & $0.35(0.22,14.1)^{c}$ & $4.7(-)^{b}$ & $3.22(-)^{b}$ \\
\hline 120 & $0.29(0.18,6.51)^{\mathrm{c}}$ & $2.57(0.19,0.78)^{\mathrm{c}}$ & $0.18(0.12,1.50)^{\mathrm{c}}$ & $0.84(-)^{\mathrm{b}}$ \\
\hline 168 & $0.79(-)^{\mathrm{b}}$ & $0.26(0.19,0.79)^{\mathrm{c}}$ & $0.18(0.12,1.51)^{\mathrm{c}}$ & $0.12(0.09,0.16)^{\mathrm{c}}$ \\
\hline \multicolumn{5}{|l|}{ A. obtectus } \\
\hline 24 & $1.43(-)^{\mathrm{b}}$ & $1.22(0.14,2.60)^{\mathrm{c}}$ & $0.36(0.20,398.0)^{\mathrm{c}}$ & $0.49(0.23,8649)^{\mathrm{c}}$ \\
\hline 72 & $0.44(0.28,1.40)^{\mathrm{c}}$ & $0.71(0.35,9.85)^{\mathrm{c}}$ & $0.61(-)^{\mathrm{b}}$ & $0.72(0.35,11.50)^{\mathrm{c}}$ \\
\hline 120 & $0.19(-)^{\mathrm{b}}$ & $0.26(-)^{\mathrm{b}}$ & $0.19(-)^{\mathrm{b}}$ & $0.26(-)^{b}$ \\
\hline 168 & $0.12(-)^{b}$ & $0.03(0.0,0.051)^{\mathrm{c}}$ & $0.28(-)^{\mathrm{b}}$ & $0.13(-)^{b}$ \\
\hline \multicolumn{5}{|l|}{ S. zeamais } \\
\hline 24 & $1.72(-)^{\mathrm{b}}$ & $0.24(0.16,0.96)^{c}$ & $0.35(0.23,114.7)^{\mathrm{c}}$ & $0.28(0.21,1.60)^{c}$ \\
\hline 72 & $0.29(0.19,1.50)^{c}$ & $0.17(0.12,0.51)^{\mathrm{c}}$ & $0.31(0.20,2.30)^{c}$ & $0.41(0.24,63.10)^{\mathrm{c}}$ \\
\hline 120 & $0.18(0.12,1.0)^{\mathrm{c}}$ & $0.07(0.04,0.09)^{\mathrm{c}}$ & $0.30(0.21,13.4)^{c}$ & $0.24(0.15,143.8)^{c}$ \\
\hline 168 & $0.07(0.04,0.10)^{\mathrm{c}}$ & $0.06(0.04,0.07)^{c}$ & $0.30(0.21,13.4)^{\mathrm{c}}$ & $0.38(0.24,10.27)^{c}$ \\
\hline
\end{tabular}

Probit Pearson Goodness -of -fit $\left(\chi^{2}=3.5-4.8\right.$, df $\left.=2, P<0.27\right)$.

${ }^{a}$ Figures in parentheses represent the lower and upper $95 \%$ confidence limits for the $\mathrm{LC}_{50}$ values.

b Significant response in Probit Regression Analysis at $\mathrm{P}<0.05$.

${ }^{\mathrm{c}}$ Insignificant responses. 

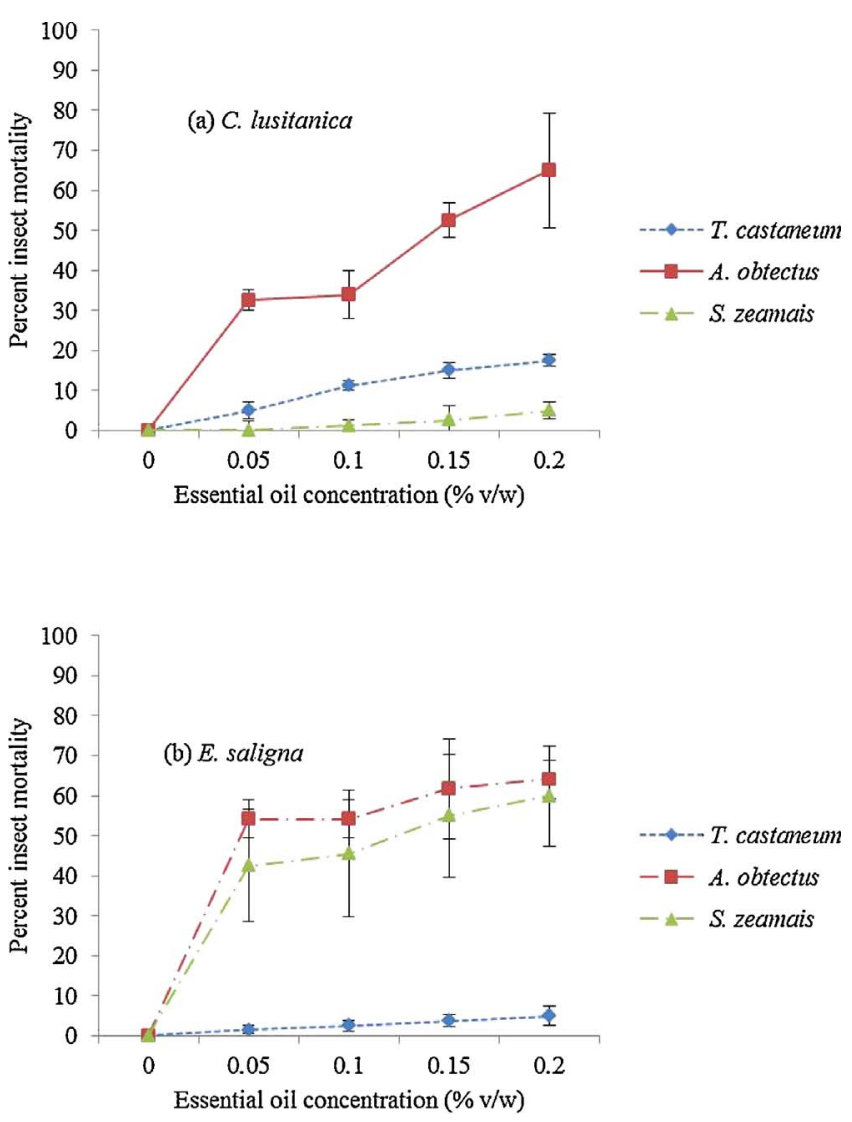

Fig. 4. Percent mortality (Mean $\pm \mathrm{SE}, \mathrm{n}=4$ ) of $T$. castaneum, A. obtectus and $S$. zeamais after 120 days contact with five concentrations (v/w) of (a) C. lusitanica and (b) E. saligna leaf essential oils.

zeamais and A. obtectus demonstrates the potential of oils in the control of stored product insect pests during long-term storage of products. However, $T$. castaneum was clearly tolerant to C. lusitanica and E. saligna essential oils for storage durations of 30-120 days at concentrations of $0.20 \% \mathrm{v} / \mathrm{w}$.

The same trend is observed in other studies where essential oils have exhibited different toxicities against coleopteran and lepidopteran insect pests of stored cereals and legumes. In short-term residual bioactivity studies with crude powders and extracts, significant adult insect mortalities and reproductive inhibitory effects against coleopteran pests of stored food commodities have also been reported (Al-Jabr, 2006; Ogendo et al., 2008a; Nivea et al., 2013). For instance, in local residual contact toxicity studies for 4-month storage duration, T. vogelii fruit essential oil had stronger residual toxicity (31-47\% kill) than leaf oil (18-21\% kill) against $S$. oryzae. The converse was true for $O$. americanum leaf oil that caused $58-75 \%$ kill of $C$. chinensis compared to $37-53 \%$ mortality rates by $T$. vogelii leaf oil (Ogendo et al., 2011). Nivea et al. (2013) reported that $O$. americanum essential oil was strongly toxic against $C$. maculatus adults $\left(\mathrm{LC}_{50}=0.23 \mu_{1} 1^{-1}\right.$ air) while the oils from Hyptis suaveolens L. (Lamiaceae), H. spicigera L. (Lamiaceae) and Lippia multiflora Moldenke (Lamiaceae) exhibited higher LC $_{50}$ values of 1.30, 5.53 and $6.44 \mu 11^{-1}$ air, respectively. The persistence of the biological activity of the four oils was variable and that from $O$. americanum was most persistent. In addition, Al-Jabr (2006) was able to demonstrate that complete mortality of Oryzaephilus surinamensis L. (Coleoptera: Silvanidae) could be achieved by Mentha viridis L. (Lamiaceae), Matricaria chamomilla L. (Asterales: Asteracae) and Cinnamomum camphora L. (Lauraceae) at concentration more than $0.5 \%$. Although, $1 \%$ of Prunus amygdalus L. (Rosaceae) and Cymbopogon winterianus L. (poaceae) gave complete mortality of $T$. castaneum after two weeks of exposure. Conversely, Rosmarinus officinalis L. (Lamiales: Lamiaceae) was the least toxic to both insect species.

The observed differential toxicity effects of C. lusitanica and E. saligna essential oils against four coleopteran pests of stored food grains could be explained by individual and/or synergistic bioactivity of major chemical constituents and differential responses by test insect species (Arriaga et al., 2005; Ogendo et al., 2013). In the current study, it was clear that $A$. obtectus were more susceptible to test essential oils compared to $S$. zeamais and $T$. castaneum. The possible explanation for this variation is the fact that adult stages of $A$. obtectus do not feed, hence become progressively weaker making them more susceptible to toxic effects of test oils. Contact toxicity of essential oils against insect pests has been associated previously to presence of 1, 8-cineole, eugenol, methyl eugenol, and limonene and $\alpha$-pinene among other bioactive essential oil constituents (Ilboudo et al., 2010; Abd-Elhady, 2012; Olivero-Verbel et al., 2013.). The insecticidal activity of eucalyptus oils

Table 3

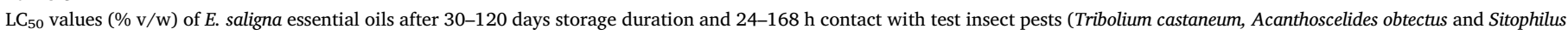
zeamais).

\begin{tabular}{|c|c|c|c|c|}
\hline \multirow[b]{2}{*}{ Insect/Time (h) } & \multicolumn{4}{|c|}{ Grain Storage Duration (Days) } \\
\hline & 30 & 60 & 90 & 120 \\
\hline \multicolumn{5}{|l|}{ T. castaneum } \\
\hline 24 & $0.17\left(0.14,25.00^{\mathrm{a}}\right)^{\mathrm{c}}$ & $0.36(-)^{\mathrm{b}}$ & $0.36(-)^{\mathrm{b}}$ & $0.36(-)^{\mathrm{b}}$ \\
\hline 72 & $0.11(0.08,0.13)^{\mathrm{c}}$ & $0.42(-)^{\mathrm{b}}$ & $0.42(-)^{b}$ & $0.48(-)^{b}$ \\
\hline 120 & $0.106(-)^{b}$ & $0.43(0.22,2126)^{\mathrm{c}}$ & $0.62(-)^{\mathrm{b}}$ & $0.73(-)^{\mathrm{b}}$ \\
\hline 168 & $0.51(0.30,2.21)^{c}$ & $0.26(0.18,1.60)^{\mathrm{c}}$ & $0.62(-)^{b}$ & $0.7(-)^{\mathrm{b}}$ \\
\hline \multicolumn{5}{|l|}{ A. obtectus } \\
\hline 24 & $0.16(-)^{\mathrm{b}}$ & $0.22(0.19,0.42)^{\mathrm{c}}$ & $0.58(-)^{\mathrm{b}}$ & $0.58(-)^{\mathrm{b}}$ \\
\hline 72 & $0.12(0.09,0.14)^{\mathrm{c}}$ & $0.16(-)^{\mathrm{b}}$ & $0.27(0.17,3.90)^{\mathrm{c}}$ & $0.59(-)^{b}$ \\
\hline 120 & $0.06(0.05,0.08)^{c}$ & $0.06(-)^{b}$ & $0.12(0.09,0.17)^{\mathrm{c}}$ & $0.12(0.09,0.17)^{\mathrm{c}}$ \\
\hline 168 & $0.003(-)^{b}$ & $0.38(0.22,4.77)^{c}$ & $0.04(-)^{\mathrm{b}}$ & $0.04(-)^{\mathrm{b}}$ \\
\hline \multicolumn{5}{|l|}{ S. zeamais } \\
\hline 24 & $0.21(-)^{\mathrm{b}}$ & $0.07(-)^{b}$ & $0.09(-)^{\mathrm{b}}$ & $0.25(-)^{b}$ \\
\hline 72 & $0.20(0.16,0.33)^{c}$ & $1.7(0.49,2687.7)^{\mathrm{c}}$ & $0.11(0.08,0.15)^{\mathrm{c}}$ & $0.12(0.99,0.15)^{\mathrm{c}}$ \\
\hline 120 & $1.79(0.49,2688.7)^{\mathrm{c}}$ & $0.06(0.03,0.08)^{c}$ & $0.06(0.03,0.08)^{c}$ & $0.12(0.99,0.15)^{\mathrm{c}}$ \\
\hline 168 & $0.005(-)^{\mathrm{b}}$ & $0.38(0.22,4.77)^{c}$ & $0.09(0.05,0.14)^{c}$ & $0.10(0.05,0.17)^{c}$ \\
\hline
\end{tabular}

Probit Pearson Goodness -of -fit ( $\chi^{2}=0.001-2.8$, df $=2, P<0.99$ ).

${ }^{a}$ Figures in parentheses represent the lower and upper $95 \%$ confidence limits for the $\mathrm{LC}_{50}$ values.

b Significant response in Probit Regression Analysis at $\mathrm{P}<0.05$.

${ }^{\mathrm{c}}$ Insignificant responses. 

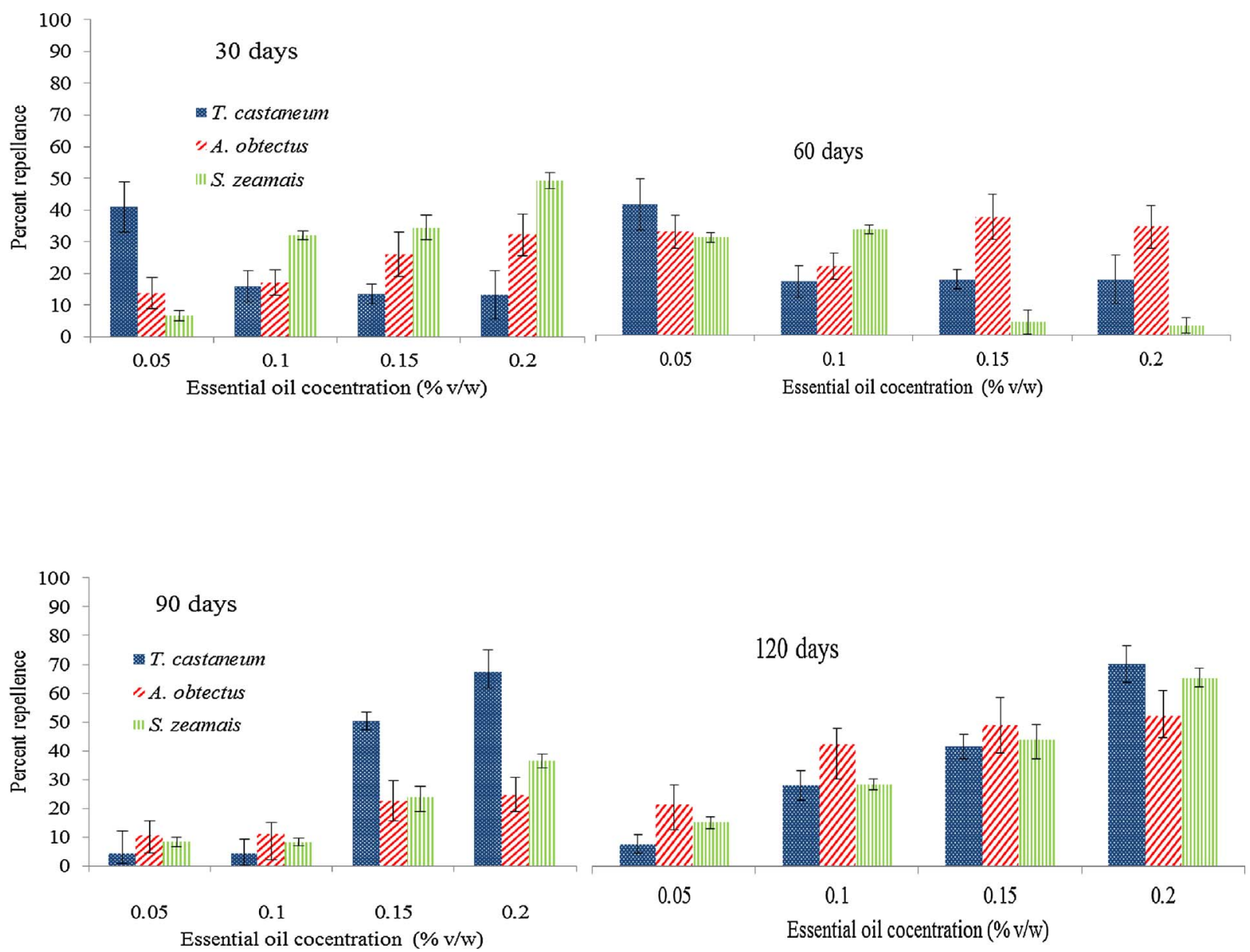

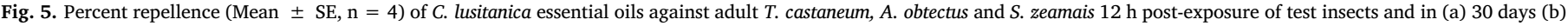
60 days (c) 90 days and (d)120 days grain storage duration.

has been associated with components such as 1, 8-cineole, citronellal, citronellol, citronellyl acetate, $p$-cymene, eucamalol, limonene, linalool, $\alpha$-pinene, $\gamma$-terpinene, $\alpha$-terpineol, alloocimene, and aromadendrene (Batish et al., 2008; Su et al., 2006; Liu et al., 2008; Bett et al., 2016).

The results of residual repellency assays of leaf essential oils of $C$. lusitanica and E. saligna against test insects showed variable responses. However, repellence was influenced by insect and plant species, concentration of oil exposure time and storage duration. Results on instant repellence have shown clearly that $C$. lusitanica essential oil was a strong repellent against $T$. castaneum at a concentration of $0.20 \% \mathrm{v} / \mathrm{w}$ after $24 \mathrm{~h}$ of exposure and moderately repellent against $S$. zeamais. $E$. saligna oil was a poor repellent in all test insects even at higher concentrations and longer exposure periods. The $C$. lusitanica essential oil main constituents umbellulone, $\alpha$-pinene could have contributed to its repellent activity against $T$. castaneum. However, minor essential constituents such as camphor, $\alpha$-terpineol, limonene (Table 1) may have contribute synergistically to the overall repellent activity of the major constituents (Mossi et al., 2011).

These results are in agreement with previous local studies in which instant repellency depended on inter-plant species, intra-plant variations, concentration, insect species. Essential oils obtained from $L$. camara, $O$. americanum, and T. vogelii were effective repellents against $S$. oryzae, $T$. castaneum, $C$. chinensis and $R$. dominica with PR values in the range of $60-83 \%$ (Ogendo et al., 2008b). Chebet et al. (2013) demonstrated that grains treated with crude powders of T. vogelii and Azadirachta indica Juss (Meliaceae) were equally the most repellent (PR values: $88-90 \%$ ) against adult $P$. truncatus followed by $L$. camara (PR 73\%). Tapondjou et al. (2005) reported essential oils and cymol ( $p$ cymene) obtained from E. saligna and C. sempervirens, to have repellent and toxic effects on $S$. zeamais and $T$. castaneum. The observed variable repellent activity could partly be attributed to the presence of volatile constituents such as monoterpenes and sesquiterpenes which are wellknown repellents of phytophagous (biting) insects by acting in the vapour form on the olfactory receptors (Lee et al., 2003; Wang et al., 2006). The highly repellent effects of the main constituents of essential oils such as 1, 8-cineole, terpineol and a-pinene have been demonstrated (Tapondjou et al., 2005; Bett et al., 2016).

The results indicate also that repellence decreased with dosage and even negative repellence (attraction) observed. It was also observed that in residual repellence assay percent repellence increased with exposure time in all test insects. The insecticidal constituents of many plant extracts and essential oils are monoterpenoids. Due to their high volatility they may be lost after long exposure periods (Regnault-Roger et al., 2012). However high volatility can be overcome by mixing essential oils with Kaolin powder (clay) and diatomaceous earths (Keita et al., 2000, 2001; Campolo et al., 2014). Fumigation of Callosobruchus maculatus L. (Coleoptera: Chrysomelidae) with Ocimum basilicum L. (Lamiaceae) and $O$. gratissimum essential oils mixed with kaolin powder caused $70-99 \%$ mortality of adults and adult emergence reduced by 0-4\% (Keita et al., 2000, 2001) compared to pure oils. In similar studies, Campolo et al. (2014) found Citrus sinensis L. (Rutaceae) essential oil showed a synergistic effect on the mortality of $R$. dominica, if combined with kaolin, and antagonistic effect when admixed with diatomaceous earth.

Similar results trend were also observed by Wambua et al. (2011) who reported a dose- and exposure time-dependent negative repellence (attraction) of Helicoverpa armigera Hubner (Lepidoptera: Noctuidae) larvae to chickpea leaves treated with aqueous extracts of $T$. vogelii. 

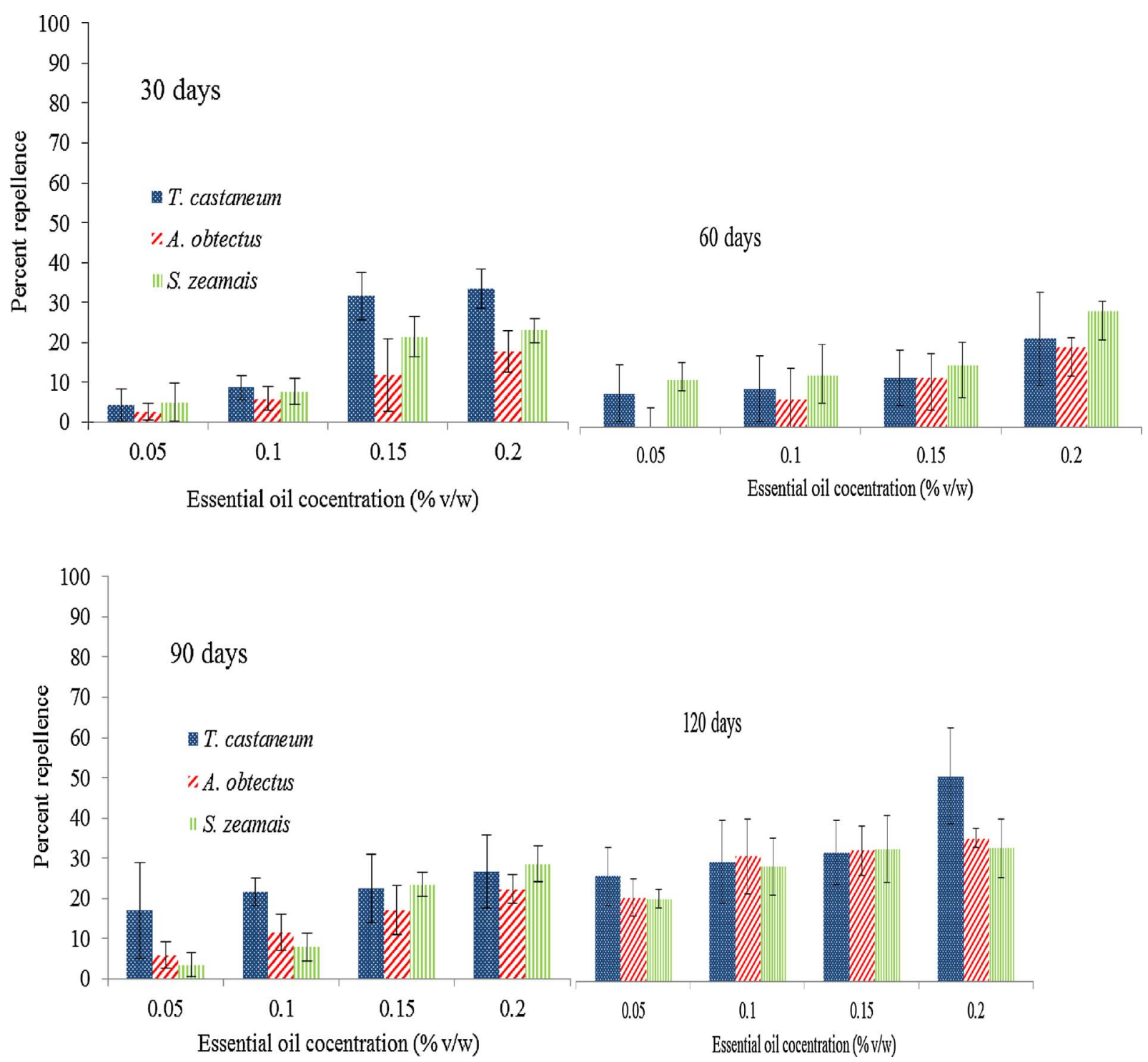

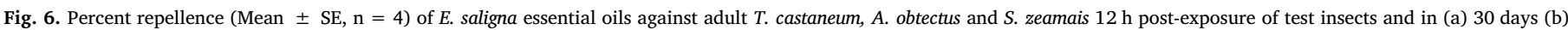
60 days (c) 90 days and (d)120 days grain storage duration.

Ogendo et al. (2003) reported that maize grains admixed with Actellic Super $^{\mathrm{TM}} 2 \%$ (Pirimiphos-methyl + Permethrin) dust registered negative PR values against $S$. zeamais due to the arrestment of test insect by the chemical. In similar studies, Ogendo et al. (2008b) reported eugenol produced PR values that decreased with dosage of $C$. chinensis on treated grains. The major cause of the negative PR values was possibly due to the high contact toxicity of eugenol (Ogendo et al., 2008b) against $C$. chinensis.

Essential oil-based insecticides are very important for the control of stored insects because they are active against a variety of insects, fast penetrating and no toxic residues in the treated products (Mbata and Payton, 2013). However, setbacks of using essential oils include volatility, solubility and oxidation, which plays an important role in the their activity, application and persistence. Plant-insecticides as compared to synthetics have manifold effects on insect pests of stored products: insecticidal, repellent and reproduction inhibition (Nerio et al., 2010; Alzogaray et al., 2011; Caballero-Gallardo et al., 2012). The combination of all these methods used simultaneously or alternately, would certainly decrease the undesirable and secondary effects of and also reduce the amounts of insecticide employed. Therefore, the moderate residual toxicity and repellence $C$. lusitanica and $E$. saligna essential oils against $T$. castaneum, A. obtectus, and $S$. zeamais can still contribute to the management of these insect pests considering also the other adverse effects of the essential oils.

\section{Conflict of interest/disclosure statement}

The above mentioned authors of this manuscript are not aware of any individual and institutional affiliations or financial support or membership that may be considered as a conflict of interest.

\section{Acknowledgements}

The authors of this manuscript wish to acknowledge the Lake Victoria Research Initiative (VicRes), Egerton University and National Council for Science, Technology and Innovation for providing funds in support of this study. We are also grateful to the International Centre of Insect Physiology and Ecology (icipe), Nairobi for providing analysis equipment. Finally Mr. Xavier Cheseto and Mr Onesmus K. Wanyama both of icpe for providing technical support during analysis process and Ms. Ann J. Kiplagat of Egerton University for assisting in bioassays. 


\section{References}

Abay, G., Karakoç, Ö.C., Tüfekçi, A.R., Koldas, S., Demirtas, I., 2012. Insecticidal activity of Hypnum cupressiforme (Bryophyta) against Sitophilus granarius (Coleoptera: Curculionidae). J. Stored Prod. Res. 51, 6-10.

Abbott, W.S., 1925. A method of computing the effectiveness of an insecticide. J. Econ. Entomol. 18, 265-267.

Abd-Elhady, H.K., 2012. Insecticidal activity and chemical composition of essential oil from Artemisia judaica L. against Callosobruchus maculatus (F.) (coleoptera: bruchidae). J. Plant Prot. Res. 52, 347-352.

Al-Jabr, A.M., 2006. Toxicity and repellency of seven plant essential oils to Oryzaephilus surinamensis (Coleoptera: Silvanidae) and Tribolium castaneum (Coleoptera: Tenebrioidae). Sci. J. King Faisal Univ. (Basic Appl. Sci.) 7, 49-58.

Arriaga, A.M.C., Magalhães, F.E.A., Feitosa, E.M.A., Malcher, G.T., Andrade-Neto, M., Nascimento, R.F., 2005. Composition of the essential oil of Tephrosia egregia Sandw. J. Essent. Oils Res. 17, 451-452.

Asawalam, E.F., Emosairue, S.O., Hassanali, A., 2006. Bioactivity of Xylopia aetiopica (Dunal) a rich essential oil constituents on maize weevil Sitophilus zeamais Motch. (Coleoptera: Curculionidae). Electron. J. Environ. Agric. Food Chem. 5, 1195-1204.

Ayvaz, A., Sagdic, O., Karaborklu, S., Ozturk, I., 2010. Insecticidal activity of the essential oils from different plants against three stored-product insects. J. Insect Sci. 10, 21-23.

Batish, D.R., Singh, H.P., Kohli, R.K., Kaur, S., 2008. Eucalyptus essential oil as a natural pesticide. For. Ecol. Manag. 256, 2166-2174.

Bett, P.K., Deng, A.L., Ogendo, J.O., Kamatenesi-Mughisha, M., Mihale, J.M., 2013. Toxic and repellent properties of Cupressus lusitanica and Eucalyptus saligna essential oils against Callosobrochus chinensis and Sitophilus zeamais. In: Ogendo, J.O., Lukhoba, C.W., Bett, P.K., Machocho, A.K. (Eds.), Proceedings of the First International Conference on Pesticidal Plants Volume 1 (August, 2013). ADAPPT-Network: Egerton University. pp. 121-123.

Bett, P.K., Deng, A.L., Ogendo, J.O., Kariuki, S.T., Kamatenesi-Mugisha, M., Mihale, J.M., Torto, B., 2016. Chemical composition of Cupressus lusitanica and Eucalyptus saligna leaf essential oils and bioactivity against major insect pests of stored food grains. Ind. Crops Prod. 82, 51-62.

Bett, P.K., 2015. Chemical Composition of Cupressus lusitanica, Miller and Eucalyptus saligna, Smith Essential Oils and Bioactivity Against Lepidopteran and Coleopteran Pests of Stored Grains. Egerton University, Kenya PhD Thesis, 144pp.

Caballero-Gallardo, K., Olivero-Verbel, J., Stashenko, E.E., 2012. Repellency and toxicity of essential oils from Cymbopogon martinii, Cymbopogon flexuosus and Lippia origanoides cultivated in Colombia against Tribolium castaneum. J. Stored Prod. Res. 50, 62-65.

Campolo, O., Agatino, V.P., Verdone, M., Palmeri, V., 2012. Survey of solid impurities and active infestation in flours produced in Calabria (Italy). J. Stored Prod. Res. 50, 36-41.

Campolo, Romeo, F.V., Malacrinò, A., Laudani, F., Carpinteri, G., Fabroni, S., Rapisarda, P., Palmeri, V., 2014. Effects of inert dusts applied alone and in combination with sweet orange essential oil against Rhyzopertha dominica (Coleoptera: Bostrichidae) and wheat microbial population. Ind. Crops Prod. 61, 361-369.

Chebet, F., Deng, A.L., Ogendo, J.O., Kamau, A.W., Bett, P.K., 2013. Bioactivity of selected plant powders against Prostephanus truncatus (Coleoptera: Bostrichidae) in stored maize grains. Plant Prot. Sci. 49, 34-43.

Deng, A.L., Ogendo, J.O., Owuor, G., Bett, P.K., Omolo, E.O., Kamatenesi-Mugisha, M., Mihale, J.M., 2009. Factors determining the use of botanical insect pest control methods by small-holder farmers in the Lake Victoria Basin, Kenya. Afr. J. Environ. Sci. Technol. 3, 108-115.

Finney, D.J., 1971. Probit Analysis, 3rd ed. Cambridge University Press, London.

Ilboudo, Z., Dabiré, L.C.B., Nébié, R.C.H., Dicko, I.O., Dugravot, S., Cortesero, A.M., Sanon, A., 2010. Biological activity and persistence of four essential oils towards the main pest of stored cowpeas, Callosobruchus maculatus (F.) (Coleoptera: Bruchidae). J. Stored Prod. Res. 46, 124-128.

Keita, S.M., Vincent, C., Schmit, J.P., Ramaswamy, S., Belanger, A., 2000. Effect of various essential oils on Callosobruchus maculatus (F.) (Coleoptera: Bruchidae). J. Stored Prod. Res. 36, 355-364.

Keita, S.M., Vincent, C., Schmit, J.P., Arnason, J.T., Belanger, A., 2001. Efficacy of essential oil of Ocimum basilicum L. and O. gratissimum L. applied as an insecticidal fumigant and powder to control Callosobruchus maculatus Fab. (Coleoptera: Bruchidae). J. Stored Prod. Res. 37 (4), 339-349.

Lee, S., Peterson, C.J., Coats, J.R., 2003. Fumigation toxicity of monoterpenoids to several stored product insects. J. Stored Prod. Res. 39, 77-85.

Liang, Y., Lu, J., Xu, S., Zhao, N.N., Zhou, L., Cheng, J., Liu, Z.L., 2013. Evaluation of repellency of some Chinese medicinal herbs essential oils against Liposcelis bostrychophila (Psocoptera: Liposcelidae) and Tribolium castaneum (Coleoptera: Tenebrionidae). J. Econ. Entomol. 106, 513-519.

Liu, X., Chen, Q., Wang, Z., Xie, L., Xu, Z., 2008. Allelopathic effects of essential oil from Eucalyptus grandis on pathogenic fungi and pest insects. For. China 3, 232-236.

Liu, Z.L., Yu, M., Li, X.M., Wan, T., Chu, S.S., 2011. Repellent activity of eight essential oils of Chinese medicinal herbs to Blattella germanica L. Rec. Nat. Prod. 5, 176-183.
Mbata, G.N., Payton, M.E., 2013. Effect of monoterpenoids on oviposition and mortality of Callosobruchus maculatus (F.) (Coleoptera: Bruchidae) under hermetic conditions. J. Stored Prod. Res. 53, 43-47.

Mossi, A.J., Astolfi, V., Kubiak, G., Lerin, L., Zanella, C., Toniazzo, G., de Oliveira, D. Treichel, H., Devilla, I.A., Cansiana, R., Restelloa, R., 2011. Insecticidal and repellency activity of essential oil of Eucalyptus sp. against Sitophilus zeamais Motschulsky (Coleoptera, Curculionidae). J. Sci. Food Agric. 91, 273-277.

Nerio, L.S., Olivero-Verbel, J., Stashenko, E., 2010. Repellent activity of essential oils: a review. Bioresour. Technol. 101, 372-378.

Nivea, M.S.G., de Oliveira, J.V., Navarro, D.M.A.F., Dutra, K.A., da Silva, W.A., 2013. Contact and fumigant toxicity and repellency of Eucalyptus citriodora Hook., Eucalyptus staigeriana F., Cymbopogon winterianus Jowitt and Foeniculum vulgare Mill. essential oils in the management of Callosobruchus maculatus (F.) (Coleoptera: Chrysomelidae, Bruchinae). J. Stored Prod. Res. 54, 41-47.

Nukenine, E.N., 2010. Stored product protection in Africa: past, present and future. In: Proceedings of the 10th International Working Conference on Stored Product Protection. Julius-Kuhn-Archiv 2010. pp. 26-41.

Ogendo, J.O., Belmain, S.R., Deng, A.L., Walker, D.J., 2003. Comparison of toxic and repellent effects of Lantana camara with Tephrosia vogelii Hook and a synthetic pesticide against Sitophilus zeamais Motsculsky (Coleoptera: Curculionidae) in stored maize grain. Insect Sci. Appl. 23, 127-135.

Ogendo, J.O., Kostyukovsky, M., Ravid, U., Matasyoh, J.C., Deng, A.L., Omolo, E.O., Kariuki, S.T., Shaaya, E., 2008a. Bioactivity of Ocimum gratissimum oil and two constituents against five insect pests attacking stored food products. J. Stored Prod. Res. 44, 328-334.

Ogendo, J.O., Kostyukovsky, M., Ravid, U., Matasyoh, J.C., Deng, A.L., Omolo, E.O., Kariuki, S.T., Shaaya, E., 2008b. Bioactivity of Ocimum gratissimum oil and two constituents against five insect pests attacking stored food products. J. Stored Prod. Res. 44, 328-334.

Ogendo, J.O., Deng, A.L., Kostyukovsky, M., Ravid, U., Matasyoh, J.C., Omolo, E.O., Kariuki, S.T., Kamau, A.W., Bett, P.K., Shaaya, E., 2011. Plant essential oils as potential toxicants and protectants of stored food commodities: is there hope for food security for smallholder farmers? In: African Crop Science Conference Proceedings 10: 229-236. African Crop Science Society.

Ogendo, J.O., Deng, A.L., Birech, R.J., Bett, P.K., 2012. Plant-based products as control agents of stored-product insect pests in the tropics. In: Bhat, R., Alias, A.K., Paliyath, G. (Eds.), Progress in Food Preservation. John Wiley \& Sons, London, pp. 581-601.

Ogendo, J.O., Deng, A.L., Kostyukovsky, M., Ravid, U., Matasyoh, J.C., Omolo, E.O., Kariuki, S.T., Kamau, A.W., Bett, P.K., Shaaya, E., 2013. Residual bioactivity of Ocimum americium L. and Tephrosia vogelii Hook essential oils against coleopteran pests and inhibition of wheat seed germination. In: Ogendo, J.O., Lukhoba, C.W., Bett, P.K., Machocho, A.K. (Eds.), Proceedings of the First International Conference on Pesticidal Plants Volume 1 (August, 2013). ADAPPT-Network: Egerton University. pp. 91-94.

Olivero-Verbel, J., Tirado-Ballestas, I., Caballero-Gallardo, K., Stashenko, E.E., 2013. Essential oils applied to the food act as repellents toward Tribolium castaneum. J. Stored Prod. Res. 55, 145-147.

Philips, T.W., Throne, J.E., 2010. Biorational approaches to managing stored product insects. Annu. Rev. Entomol. 55, 375-397.

Rajendran, S., Sriranjini, V., 2008. Plant products as fumigants for stored-product insect control (Review). J. Stored Prod. Res. 44, 126-135.

Regnault-Roger, C., Vincent, C., Arnason, J.T., 2012. Essential oils in insect control: lowrisk products in a high-stakes world. Rev. Entomol. 57, 405-424.

Rosman, V., Kalinovic, I., Korunic, Z., 2007. Toxicity of naturally occurring compounds of Lamiaceae and Lauraceae to three stored-product insects. J. Stored Prod. Res. 43, 349-355.

SPSS, 2010. SPSS Version 19. IBM Inc.

Sokal, R.R., Rohlf, F.J., 1995. Biometry, 3rd ed. Freedman and Company, New York.

Su, Y.C., Ho, C.L., Wang, I.C., Chang, S.T., 2006. Antifungal activities and chemical compositions of essential oils from leaves of four eucalyptus. Taiwan J. For. Sci. 21, 49-61.

Tapondjou, A.L., Adler, C., Fontem, D.A., Bouda, H., Reichmuth, C., 2005. Bioctivities of cymol and essential oils of Cupressus sempervirens and Euacalyptus saligna against Sitophilus zeamais Motschulsky and Tribolium confusum du Val. J. Stored Prod. Res. 41, 91-102.

Toloza, A., Czygadlo, J., Cueto, G.M., Biurrun, F., Zerba, E., Picollo1, M., 2006. Fumigant and repellent properties of essential oils and component compounds against permethrin-resistant Pediculus humanus capitis (Anoplura: Pediculidae) from Argentina. J. Med. Entomol. 43, 889-895.

Wambua, L.M., Deng, A.L., Ogendo, J.O., Owuoche, J., Bett, P.K., 2011. Toxic, antifeedant and repellent activity of aqueous crude extracts of Tephrosia vogelii Hook on the larval stages of Helicoverpa armigera Hubner. Baraton Interdiscip. Res. J. 1, 19-29.

Wang, J., Zhu, F., Zhou, X.M., Niu, C.Y., Lei, C.L., 2006. Repellent and fumigant activity of essential oil from Artemisia vulgaris to Tribolium castaneum (Herbst) (Coleoptera: Tenebrionidae). J. Stored Prod. Res. 42, 339-347. 